\title{
High-Lipid Diet Intake Is a Possible Predisposing Factor in the Development of Hypogonadal Osteoporosis
}

\author{
S. Chanda, M. N. Islam, P. Pramanik, and C. Mitra \\ Department of Physiology, Presidency College, Calcutta, India
}

\begin{abstract}
The effects of a high-lipid diet on the intestinal transference of $\mathrm{Ca}^{2+}$ and the activities of intestinal enzymes were studied in ovariectomized rats. The plasma $\mathrm{Ca}^{2+}$ level and urinary loss of $\mathrm{Ca}^{2+}$ were also observed. Ovariectomy decreased both alkaline phosphatase (AP) and calcium ATPase $\left(\mathrm{Ca}^{2+}\right.$-ATPase) activity, and also reduced the mucosal transference of $\mathrm{Ca}^{2+}$ in all parts of the small intestine. Although the plasma
\end{abstract}

$\mathrm{Ca}^{2+}$ level did not change significantly, the urinary loss of $\mathrm{Ca}^{2+}$ was enhanced. A high-lipid diet supplement enhanced all these parameters in ovariectomized rats. It is therefore believed that a high-lipid diet may promote osteoporosis in ovariectomized rats as the result of $\mathrm{Ca}^{2+}$ transfer and enhanced urinary $\mathrm{Ca}^{2+}$ loss. [Japanese Journal of Physiology, 46, 383-388, 1996]

Key words: ovariectomy, high-lipid diet, intestinal transference and urinary loss of $\mathrm{Ca}^{2+}$, osteoporosis.

In women, osteoporosis occurs particularly after menopause. Physiological states such as a decrease in estrogen level result in a more rapid onset of loss in bone mass which may lead to osteoporosis [1]. Other predisposing factors for osteoporosis are adrenal cortex hyperfunction, corticosteroid therapy, hyperthyroidism, prolonged calcium deficiency, and prolonged physical immobilization [2]. Hypocalcemia is the primary stimulus for the secretion of parathormone (PTH), which may be due to a reduction in the transference of $\mathrm{Ca}^{2+}$ from the intestine or because of decreased renal reabsorption $[3,4]$. The involvement of alkaline phosphatase (AP) and calcium ATPase $\left(\mathrm{Ca}^{2+}\right.$. ATPase) in calcium absorption has been proposed by many researchers, because the activities of these enzymes correlate with the degree of calcium absorption in different parts of the intestinal tract under different circumstances $[5,6]$. Furthermore, the activity of calcium $\left(\mathrm{Ca}^{2+}\right)$ - and magnesium $\left(\mathrm{Mg}^{2+}\right)$-dependent ATPase present in intestinal brush borders is increased by vitamin D [7]. A similar dependency of AP activity on vitamin $D$ has also been reported $[8,9]$. It is suggested that AP and brush border $\mathrm{Ca}^{2+}$-ATPase are expressions of the same molecule $[8,10,11]$ since attempts to separate these activities by various biochem- ical procedures have not been successful [12]. It has also been reported that $\mathrm{AP}-\mathrm{Ca}^{2+}$-ATPase complex, present in both the brush border and basolateral plasma membrane of intestinal cells, has low affinity for $\mathrm{Ca}^{2+}$ and is distinct from high-affinity $\mathrm{Ca}^{2+}$-stimulated ATPase, which is present primarily in basolateral membrane [13]. An increase in the fat content of diets for infants has been reported to decrease the efficiency of $\mathrm{Ca}^{2+}$ absorption [14]. Moreover, $\mathrm{Ca}^{2+} \mathrm{ab}-$ sorption has been reported to be poorer in rats maintained on a high-fat diet [15-17].

The purpose of this study, in view of the above, is to determine the intestinal transference of $\mathrm{Ca}^{2+}$ in situ in ovariectomized rats supplemented with a high-lipid diet and note the changes in the activities of relevant enzymes, particularly of $\mathrm{AP}$ and $\mathrm{Ca}^{2+}$-ATPase, by a parallel assessment of the $\mathrm{Ca}^{2+}$ level in both plasma and urine.

\section{MATERIALS AND METHODS}

Animals. Female Wistar rats weighing 120 $150 \mathrm{~g}$ were used in all experiments. For experiments, the rats were divided into three groups: A (control), B (ovariectomized), and $\mathrm{C}$ (ovariectomized maintained 
on a high-lipid diet). The animals of groups $\mathrm{B}$ and $\mathrm{C}$ were ovariectomized by bilateral, dorsolateral incision under light ether anaesthesia, while the animals of group A were Sham-operated. The animals of all groups were provided with a control diet [18] composed of carbohydrates (equal parts of arrowroot starch and sucrose) $71 \%$, protein (casein) $18 \%$, fat (groundnut oil) 7\%, and salt mixture [19] 4\%, and vitamins were supplied according to Chatterjee et al. [20]. The animals were maintained on this diet for 1 week after operation. After 1 week, the animals of group $C$ were supplied with a high-lipid diet [21] for $15 \mathrm{~d}$, while groups A and B were provided with a normal diet. The composition of high-lipid diet included $48 \%$ carbohydrates (equal parts of arrowroot starch and sucrose) and 30\% fat (groundnut oil). The other ingredients of the diet and the supply of vitamins were the same as described above [18]. The animals of all groups were maintained on a $12 \mathrm{~h}$ light/dark schedule with free access to water supply. During the period of diet supplement, group A was pair-fed with experimental groups $\mathrm{B}$ and $\mathrm{C}$ so as to overcome the impact of any altered food intake in the experimental groups.

Preparation of intestinal loops. After the experimental period was over, the animals of all groups were fasted for $16 \mathrm{~h}$ and then anaesthetized with urethane $(1.7 \mathrm{mg} / \mathrm{g} \mathrm{bw})$. The preparation of intestinal loops for the study of $\mathrm{Ca}^{2+}$ transference in situ, was made following the method of Levine et al. [22]. The abdomen of each animal was opened through a midline incision and duodenal, jejunal and ileal segments were located. Two ligatures, one proximal and the other distal, were each applied tightly in loops measuring about $8 \mathrm{~cm}$ in all duodenal, jejunal, and ileal segments. Loops were selected so that each contained 8-10 blood vessels, and care was taken so that no major blood vessels were occluded by the ligature.

Measurement of intestinal $\mathrm{Ca}^{2+}$ transference. For the measurement of intestinal $\mathrm{Ca}^{2+}$ transference, $1 \mathrm{ml}$ of Tris- $\mathrm{HCl}$ buffer solution containing $0.2 \mathrm{mM} \mathrm{CaCl}_{2}$ was injected into the lumen of each loop with a syringe. The Tris- $\mathrm{HCl}$ buffer solution was prepared following the method of Singh et al. [23], and had the following composition (in $\mathrm{mM}$ ): $\mathrm{NaCl}$ $140.0, \mathrm{KCl} 6.0$, and Tris buffer 4, $\mathrm{pH}$ 6.9. The intestinal loops were placed in their usual positions and the abdomen was closed. After $1 \mathrm{~h}$, animals were sacrificed, the preselected loops were removed and the fluid from each loop was collected separately, together with a few washings of the lumen with doubled distilled water. The collected fluid was then increased to a definite volume with distilled water. A fraction of this fluid was then used for the estimation of $\mathrm{Ca}^{2+}$ using a double-beam spectrophotometer (Shimadzu, $160 \mathrm{~A}$ ) according to the method described by Adeniyi et al. [24]. The difference between the amount of $\mathrm{Ca}^{2+}$ introduced and the amount left unabsorbed was used to estimate the amount of $\mathrm{Ca}^{2+}$ absorbed. The intestinal part constituting the loop was dried on a watch glass in an electric oven at $90^{\circ} \mathrm{C}$ to attain a constant weight, which was recorded as the weight of the dried loop.

Preparation of enzyme extracts. After sacrificing the animal and opening the abdomen, the whole of the small intestine was quickly removed. The portion comprised of the duodenum, jejunum, and ileum were separated and chilled in ice. Intestinal mucosa was collected as described by Maenz and Cheeseman [25], and the scrapings were homogenized according to the method of Koyama et al. [26]. Mucosal scrapings were homogenized with 5 volumes of Tris- $\mathrm{HCl}$ buffer ( $\mathrm{pH} 7.4$ ).

Estimation of enzyme activities. The activity of AP was estimated using the $p$-nitrophenyl phosphate method of Maenz and Cheeseman [25]. The protein content of the homogenates, used for the study was determined essentially following the method described by Lowry et al. [27]. The activity of $\mathrm{Ca}^{2+}-\mathrm{AT}$ Pase was studied according to the method of Rorive and Kleinzeller [28]. Phosphate liberated during enzyme activity was estimated by the method of Lowry and Lopez [29].

Estimation of urinary $\mathrm{Ca}^{2+}$. For urine collection, standard laboratory procedures were adopted as described elsewhere by Nath [30]. Briefly, the animals were kept in sufficiently spaced small, round cages under a normal $12 \mathrm{~h}$ light/dark schedule. They were fasted for $24 \mathrm{~h}$, but allowed an unrestricted water supply. The entirety of each cage was placed over a glass funnel which had a long neck inserted into a measuring cylinder, and urine was collected for $24 \mathrm{~h}$ (9 A.M. to 9 A.M.). The exposed surface of the measuring cylinder was covered with parafilm to avoid evaporative loss, if any, during collection. Care was taken to assure that water was not be spilled into the measuring cylinder. No preservative was used to collect the urine for the estimation of urinary $\mathrm{Ca}^{2+}$, as described elsewhere by Nath [30]. The urine thus collected was immediately placed in a refrigerator. Total volume was measured, and the $\mathrm{Ca}^{2+}$ content was estimated according to the method described by Adeniyi et al. [24].

Estimation of plasma $\mathrm{Ca}^{2+}$. Samples were collected directly from the heart from rats under general anaesthesia. Heparin was used as the anticoagu- 
lant. Plasma $\mathrm{Ca}^{2+}$ was estimated according to the method described by Adeniyi et al. [24] using a spectrophotometer (Shimadzu, 160A).

Data. Data were expressed as mean \pm SE. Since all of the changes except in one experiment were unidirectional, significance was determined using the one-tail Student's $t$-test. Differences were considered significant if $p<0.05$.

\section{RESULTS}

\section{Mucosal transference of calcium}

The effects of a supplemental high-lipid diet on the mucosal transference of calcium in the duodenum, jejunum, and ileum of ovariectomized rats are shown in Table 1. These results indicate that a bilateral ovariec- tomy significantly $(p<0.05)$ reduces the mucosal transference of calcium in duodenum (by $13.20 \%$ ), jejunum (by 11.42\%), and ileum (by 14.28\%). Additionally, the supplemental diet causes calcium transference to be further reduced throughout the small intestine (duodenum, 22.88\%; jejunum, 19.53\%; and ileum, $27.02 \%$ ).

\section{Alkaline phosphatase activity}

Table 2 shows the effects of a supplemental highlipid diet on the mucosal alkaline phosphatase (AP) activity in the duodenal, jejunal, and ileal extracts of ovariectomized rats. The results show a significant $(p<0.05)$ reduction in AP activity in all parts of the small intestine (duodenum, 29.50\%; jejunum, $23.00 \%$; and ileum, 23.60\%). Additionally, the sup-

Table 1. Effects of a supplemental high-lipid diet on the intestinal transference of $\mathrm{Ca}^{2+}$ in ovariectomized rats.

\begin{tabular}{|c|c|c|c|c|c|c|c|c|c|}
\hline \multirow{2}{*}{$\begin{array}{l}\text { Segment } \\
\text { of small } \\
\text { intestine }\end{array}$} & \multirow{2}{*}{$\begin{array}{c}\text { Group A } \\
\text { (pair-fed } \\
\text { control) }\end{array}$} & \multirow{2}{*}{$\begin{array}{c}\text { Group B } \\
\text { (bilateral } \\
\text { ovariectomy) }\end{array}$} & \multirow{2}{*}{$\begin{array}{c}\text { Group C } \\
\text { (bilateral } \\
\text { ovariectomy+ } \\
\text { high-lipid diet) }\end{array}$} & \multicolumn{3}{|c|}{ Significant level } & \multicolumn{3}{|c|}{$\%$ decrease } \\
\hline & & & & Avs. B & Avs. C & B vs. C & $A v s . B$ & A vs. C & $B$ vs. C \\
\hline Duodenum & $7.65 \pm 0.37$ & $6.64 \pm 0.29$ & $5.90 \pm 0.11$ & $p<0.05$ & $p<0.01$ & $p<0.01$ & 13.20 & 22.88 & 11.14 \\
\hline Jejunum & $7.27 \pm 0.20$ & $6.44 \pm 0.15$ & $5.85 \pm 0.10$ & $p<0.01$ & $p<0.01$ & $p<0.01$ & 11.42 & 19.53 & 9.16 \\
\hline ileum & $6.44 \pm 0.28$ & $5.52 \pm 0.32$ & $4.70 \pm 0.20$ & $p<0.05$ & $p<0.01$ & $p<0.05$ & 14.28 & 27.02 & 14.85 \\
\hline
\end{tabular}

Values are expressed as mean $\pm \mathrm{SE}(n=5) . \mathrm{Ca}^{2+}$ transference is expressed in $\mu \mathrm{mol} / \mathrm{g} \mathrm{dry}$ wt/h.

Table 2. Effects of a supplemental high-lipid diet on the alkaline phosphatase activity of small intestinal extracts of ovariectomized rats.

\begin{tabular}{|c|c|c|c|c|c|c|c|c|c|}
\hline \multirow{2}{*}{$\begin{array}{l}\text { Segment } \\
\text { of small } \\
\text { intestine }\end{array}$} & \multirow{2}{*}{$\begin{array}{c}\text { Group A } \\
\text { (pair-fed } \\
\text { control) }\end{array}$} & \multirow{2}{*}{$\begin{array}{c}\text { Group B } \\
\text { (bilateral } \\
\text { ovariectomy) }\end{array}$} & \multirow{2}{*}{$\begin{array}{c}\text { Group C } \\
\text { (bilateral } \\
\text { ovariectomy+ } \\
\text { high-lipid diet) }\end{array}$} & \multicolumn{3}{|c|}{ Significant level } & \multicolumn{3}{|c|}{$\%$ decrease } \\
\hline & & & & A vs. B & A vs. C & B vs. C & Avs. B & A vs. C & B vs. C \\
\hline Duodenum & $237.4 \pm 12.9$ & $167.3 \pm 10.8$ & $158.9 \pm 5.3$ & $p<0.01$ & $p<0.01$ & N.S. & 29.5 & 33.1 & 5.0 \\
\hline Jejunum & $151.1 \pm 7.5$ & $116.4 \pm 4.2$ & $104.6 \pm 1.4$ & $p<0.01$ & $p<0.01$ & $p<0.05$ & 23.0 & 30.8 & 10.1 \\
\hline Ileum & $85.5 \pm 2.7$ & $65.3 \pm 2.2$ & $52.7 \pm 4.5$ & $p<0.01$ & $p<0.01$ & $p<0.05$ & 23.6 & 38.4 & 19.3 \\
\hline
\end{tabular}

Values are expressed as mean \pm SE $(n=5)$. Alkaline phosphatase activity is expressed as $p$-nitrophenol liberated in $\mu$ mol/g protein $/ \mathrm{min}$ at $37^{\circ} \mathrm{C}$. N.S. denotes not significant.

Table 3. Effects of a supplemental high-lipid diet on the Ca $\mathrm{a}^{2+}$-ATPase activity of small intestinal extracts of ovariectomized rats.

\begin{tabular}{|c|c|c|c|c|c|c|c|c|c|}
\hline \multirow{2}{*}{$\begin{array}{l}\text { Segment } \\
\text { of small } \\
\text { intestine }\end{array}$} & \multirow{2}{*}{$\begin{array}{c}\text { Group A } \\
\text { (pair-fed } \\
\text { control) }\end{array}$} & \multirow{2}{*}{$\begin{array}{c}\text { Group B } \\
\text { (bilateral } \\
\text { ovariectomy) }\end{array}$} & \multirow{2}{*}{$\begin{array}{c}\text { Group C } \\
\text { (bilateral } \\
\text { ovariectomy+ } \\
\text { high-lipid diet) }\end{array}$} & \multicolumn{3}{|c|}{ Significant level } & \multicolumn{3}{|c|}{$\%$ decrease } \\
\hline & & & & Avs. B & Avs. C & B vs. C & $A$ vs. B & Avs. C & B vs. C \\
\hline Duodenum & $16.3 \pm 0.66$ & $13.8 \pm 0.32$ & $11.2 \pm 0.63$ & $p<0.01$ & $p<0.01$ & $p<0.01$ & 15.3 & 31.3 & 18.8 \\
\hline Jejunum & $11.4 \pm 0.74$ & $8.8 \pm 0.15$ & $8.0 \pm 0.27$ & $p<0.01$ & $p<0.01$ & $p<0.05$ & 22.8 & 29.8 & 9.1 \\
\hline Ileum & $7.7 \pm 0.33$ & $6.1 \pm 0.33$ & $5.3 \pm 0.16$ & $p<0.01$ & $p<0.01$ & $p<0.05$ & 20.8 & 31.2 & 13.1 \\
\hline
\end{tabular}

Values are expressed as mean \pm SE $(n=5) . \mathrm{Ca}^{2+}$-ATPase activity is expressed as phosphate liberated in $\mu \mathrm{mol} / \mathrm{g} \mathrm{protein} / \mathrm{min}$ at $37^{\circ} \mathrm{C}$. 
S. CHANDA et al.

Table 4. Effects of a supplemental high-lipid diet on the urinary $\mathrm{Ca}^{2+}$ excretion of ovariectomized rats.

\begin{tabular}{|c|c|c|c|c|c|c|c|c|}
\hline \multirow{2}{*}{$\begin{array}{c}\text { Group A } \\
\text { (pair-fed } \\
\text { control) }\end{array}$} & \multirow{2}{*}{$\begin{array}{c}\text { Group B } \\
\text { (bilateral } \\
\text { ovariectomy) }\end{array}$} & \multirow{2}{*}{$\begin{array}{c}\text { Group C } \\
\text { (bilateral } \\
\text { ovariectomy+ } \\
\text { high-lipid diet) }\end{array}$} & \multicolumn{3}{|c|}{ Significant level } & \multicolumn{3}{|c|}{$\%$ increase } \\
\hline & & & A vs. B & A vs. C & B vs. C & Avs. B & Avs. C & B vs. C \\
\hline $3.27 \pm 0.08$ & $9.61 \pm 0.55$ & $11.22 \pm 0.28$ & $p<0.01$ & $p<0.01$ & $p<0.05$ & 194 & 243 & 17 \\
\hline
\end{tabular}

Values are expressed as mean $\pm \mathrm{SE}(n=5)$. Urinary $\mathrm{Ca}^{2+}$ excretion is expressed in $\mathrm{mg} / 24 \mathrm{~h}$ urine.

Table 5. Effects of a supplemental high-lipid diet on the plasma $\mathrm{Ca}^{2+}$ level of ovariectomized rats.

\begin{tabular}{|c|c|c|c|c|c|c|c|c|}
\hline \multirow{2}{*}{$\begin{array}{c}\text { Group A } \\
\text { (pair-fed } \\
\text { control) }\end{array}$} & \multirow{2}{*}{$\begin{array}{c}\text { Group B } \\
\text { (bilateral } \\
\text { ovariectomy) }\end{array}$} & \multirow{2}{*}{$\begin{array}{c}\text { Group C } \\
\text { (bilateral } \\
\text { ovariectomy+ } \\
\text { high-lipid diet) }\end{array}$} & \multicolumn{3}{|c|}{ Significant level } & \multicolumn{3}{|c|}{$\%$ increase } \\
\hline & & & $A$ vs. $B$ & A vs. C & B vs. C & $A$ vs. $B$ & A vs. C & B vs. C \\
\hline $7.12 \pm 0.11$ & $7.20 \pm 0.35$ & $7.38 \pm 0.18$ & N.S. & N.S. & N.S. & 1.12 & 3.65 & 2.50 \\
\hline
\end{tabular}

Values are expressed as mean $\pm \mathrm{SE}(n=5)$. Plasma $\mathrm{Ca}^{2+}$ expressed in $\mathrm{mg} / 100 \mathrm{ml}$. N.S. denotes not significant.

plemental diet causes AP activity to be further reduced throughout the small intestine (duodenum, $33.10 \%$; jejunum, $30.80 \%$; and ileum, $38.40 \%$ ).

\section{Calcium-ATPase activity}

The effects of a supplemental high-lipid diet on the mucosal $\mathrm{Ca}^{2+}$-ATPase activity in the duodenal, jejunal, and ileal extracts of ovariectomized rats are shown in Table 3. The results show that a bilateral ovariectomy causes marked $(p<0.05)$ reductions in the activity of this enzyme; about $15.30 \%$ in the duodenum, $22.80 \%$ in the jejunum, and $20.80 \%$ in the ileum. Additionally our results suggest that a supplemental high-lipid diet given to ovariectomized rats produces a further reduction of $\mathrm{Ca}^{2+}$-ATPase activity throughout the small intestine (by duodenum, $31.30 \%$; jejunum, $29.80 \%$; and ileum, $31.20 \%$ ).

\section{Urinary $\mathrm{Ca}^{2+}$ excretion}

Table 4 shows the effects of a supplemental highlipid diet on the urinary $\mathrm{Ca}^{2+}$ excretion of ovariectomized rats. A significant increase in $\mathrm{Ca}^{2+}$ excretion $(p<0.05,1.94 \%)$ through urine was noted in all of the ovariectomized rats. Additionally, the supplemental diet enhanced the excretion of $\mathrm{Ca}^{2+}$ through urine $(243 \%)$.

\section{Plasma $\mathrm{Ca}^{2+}$ level}

Table 5 shows the effects of a supplemental highlipid diet on the plasma $\mathrm{Ca}^{2+}$ levels of ovariectomized rats. An insignificance in the plasma $\mathrm{Ca}^{2+}$ level $(p>0.05,1.12 \%)$ was noted in all of the ovariectomized rats. The supplemental diet did not alter the plasma $\mathrm{Ca}^{2+}$ level significantly although a marginal increase was noted $(2.5 \%)$.

\section{DISCUSSION}

The principal finding of this study is that the intestinal transference of $\mathrm{Ca}^{2+}$ is reduced in ovariectomized rats (Table 1). This was further enhanced when the animals were fed a supplemental high-lipid diet (Table 1), suggesting that high-lipid diets have a detrimental effect rather than a positive or recovery influence on $\mathrm{Ca}^{2+}$ transference under the conditions of our study. This observation substantiates earlier reports that $\mathrm{Ca}^{2+}$ transference efficiency is affected by high-lipid diets in rats [15-17] and infants [14]. In addition, earlier reports suggest that many important cell functions like transport processes are affected by modulation of the activities of the membrane enzymes through changing fatty acyl unsaturation. Such unsaturation has been reported to be induced in the membranes of cells subjected to dietary fat supplementation. It has also been well documented that a significant proportion of the unsaturated fatty acyl moiety in mammalian cell membranes are required to maintain a "fluid" state for the proper activity of a number of membrane proteins, such as $\left(\mathrm{Na}^{+}+\mathrm{K}^{+}\right)$-ATPase, $\mathrm{Ca}^{2+}$-ATPase, and $\mathrm{Mg}^{2+}$-ATPase [31]. It may therefore be plausible that the supplementation of a highlipid diet in our study possibly influenced membrane unsaturation, thus affecting membrane protein activities and resulting in an inhibition of $\mathrm{Ca}^{2+}$ transference.

$\mathrm{Ca}^{2+}$ transference showed segmental variation, and 
was seen to have a descending gradient from the duodenum to the ileum, irrespective of groups (Table 1). This corroborates well with the earlier observation of Wills [32].

Our results also suggest that ovarian hormones possibly have an influence on the intestinal transference of $\mathrm{Ca}^{2+}$ in bilaterally ovariectomized animals, as these specimens showed a greater percentile decrease in the transference of $\mathrm{Ca}^{2+}$ than the control animals. This perhaps correlates with the finding that the hydroxylation of Vit D in the kidney is modulated by estrogen [33]. A reduction of estrogen level in the serum due to bilateral ovariectomy, thus, possibly inhibited hydroxylation of 25-hydroxy Vit $\mathrm{D}_{3}$ to 1,25-dihydroxy Vit $D_{3}$, thereby reducing the intestinal transference of $\mathrm{Ca}^{2+}$. This is well in agreement with the suggestion of Marshall and Nardin [34] that Vit D metabolites are effective in postmenopausal patients suffering. from the malabsorption of $\mathrm{Ca}^{2+}$ from the intestine. References abound that suggest the hydroxylation of Vit D is modulated by estrogen in chicks [33], Japanese quail [35], bullfrogs, and in rats [36]. In addition, primary abnormality in the metabolism of 25-hydroxy Vit $D_{3}$ to 1,25-dihydroxy Vit $D_{3}$ has also been observed in aging rats [37].

The results of our experiments with AP and $\mathrm{Ca}^{2+}$ ATPase suggest that, irrespective of groups, both of these enzymes show segmental variation in their activities in rat small intestine (Tables 2 and 3 ). This confirms the earlier observation of Toofanian and Teshfam [38]. Our results also indicate that $\mathrm{AP}$ and $\mathrm{Ca}^{2+}$ ATPase contribute significantly in the regulation of intestinal $\mathrm{Ca}^{2+}$ transference, confirming the earlier observation of Wasserman and Fullmer [39]. The activities of both of these enzymes were inhibited significantly in bilaterally ovariectomized rats as well as in groups of rats fed a high-lipid diet supplement. This suggests that the possible cause of reduced $\mathrm{Ca}^{2+}$ transference in such animals might be the inhibition of the activities of these enzymes, as both enzymes have been reported to be involved in $\mathrm{Ca}^{2+}$ transference [39]. However, the type of $\mathrm{Ca}^{2+}$-ATPase, whether $\mathrm{Ca}^{2+}$-ATPase in the brush border membranes or $\mathrm{Ca}^{2+}, \mathrm{Mg}^{2+}$-ATPase in the basolateral membranes, affected under the conditions of our experiment cannot be ascertained on the basis of our observed results, and therefore requires further investigation. Earlier, Singh et al. [23] confirmed this observation, suggesting that the AP activity of rat ileal extract might be under the control of estrogen. The enzymes, AP and $\mathrm{Ca}^{2+}$-ATPase, showed similar patterns of activity in our studies (Tables 2 and 3). This confirmed all earlier suggestions $[8,10,11]$ that both enzymes are ex- pressions of the same molecule.

In ovariectomized rats, we observed an increased loss of urinary $\mathrm{Ca}^{2+}$ (Table 4). This loss was further enhanced when the animals were supplemented a high-lipid diet (Table 4). Under similar situations, however, the plasma $\mathrm{Ca}^{2+}$ level was not altered significantly (Table 5). This is well in agreement with an earlier report that no significant change in the serum $\mathrm{Ca}^{2+}$ level occurs in oophorectomized women [40].

The results of our experiments suggest that both the conditions (ovariectomized and ovariectomized with high-lipid diet) may be highly conducive to the development of a hypocalcemic condition as urinary $\mathrm{Ca}^{2+}$ loss in the experimental animals was also associated with reduced intestinal transference of $\mathrm{Ca}^{2+}$. This seems reasonable, as increased $\mathrm{Ca}^{2+}$ excretion through urine and the simultaneous reduction in the intestinal transfer of $\mathrm{Ca}^{2+}$ are two of the most important causes for the development of hypocalcemia [3, 4].

It appears, thus, that in ovariectomized rats, a hypocalcemia possibly develops which increases PTH secretion secondarily $[3,4]$. This is well in agreement with an earlier suggestion that a secondary increase in PTH secretion might be responsible for hypogonadal osteoporosis [41].

Our results, most importantly, further reveal that high-lipid diet intake is a possible predisposing factor for osteoporosis in a hypogonadal situation, in as much as $\mathrm{Ca}^{2+}$ transference and loss are concerned.

\section{REFERENCES}

1. Rhoades R and Pflanzer R: Human Physiology, Saunders College Publishing, Philadelphia, pp 800-822, 1989

2. Keel $A C$, Neil E, and Joels N: Samson Wright's Applied Physiology, Oxford University Press, Delhi, p 555, 1983

3. Martin DW, Mayes PA, and Rodwell WW: Harper's Review of Biochemistry, Lange Medical Publications, Stanford, pp 116-119, 1981

4. Aurbach GD, Marx SJ, and Spiegel AM: Parathyroid hormone, Calcitonin, and Calciferols. In: Williams Text Book of Endocrinology, ed. Wilson JD and Foster DW, WB Saunders Co, Philadelphia, 8th ed, pp 1443-1446, 1992

5. Feher $\mathrm{JJ}$ and Wasserman FHt: Intestinal calcium-binding protein and calcium absorption in cortisol treated chicks: Effects of vitamin $D_{3}$ and 1, 25-dihydroxy vitamin $D_{3}$. Endocrinology 104: 547-551, 1979

6. Schiffle $\mathrm{H}$ and Binswanger $\mathrm{U}: \mathrm{Ca}^{2+}$-ATPase and intestinal calcium transport in uremic rats. Am J Physiol 238 G424-G428, 1980

7. Melancon MJ and DeLuca HF: Vitamin D stimulation of calcium-dependent ATPase in chick intestinal brush borders. Biochemistry 9: 1658-1664, 1970

8. Haussler MR, Nagoda LA, and Rasmussen $\mathrm{H}$ : Induc- 


\section{S. CHANDA et al.}

tion of intestinal brush border alkaline phosphatase by vitamin D and identity with $\mathrm{Ca}^{2+4}$-ATPase. Nature 228: 1199-1201, 1970

9. Norman AW, Mircheff AK, Adams TH, and Spielvogel A: Vitamin D mediated increase of intestinal brush broder alkaline phosphatase activity. Biochim Biophys Acta 215: 348-359, 1970

10. Holdsworth ES: The effect of vitamin D on enzyme activities in the mucosal cells of the chick small intestine. J Membr Biol 3: 43-53, 1970

11. Russell RGG, Monod A, Bonjour JP, and Fleisch H: Relation between alkaline phosphatase and $\mathrm{Ca}^{2+}$-ATPase in calcium transport. Nature (New Biol) 240: 126-127. 1972

12. Oku $\mathrm{T}$ and Wasserman $\mathrm{RH}$ : Properties of vitamin $\mathrm{D}$ stimulated calcium-dependent adenosine-triphosphatase and alkaline phosphatase in chick intestinal brush border. Fed Proc 37: 408, 1978

13. Ghijsen WEJM, DeJong MD, and Van Os $\mathrm{CH}$ : Association between $\mathrm{Ca}^{2+}$-ATPase and alkaline phosphatase activities in plasma membranes of rat duodenum. Biochim Biophys Acta 599: 538-551, 1980

14. Telfer SV: Studies on calcium and phosphorus metabolism. Part I. The excretion of calcium and phosphorus. Q J Med 16: 45-62, 1922

15. French CE: The interrelation of calcium and fat utilization in the growing albino rat. J Nutr 23: 375-384, 1942

16. French CE and Elliot RF: The interrelation of calcium and fat utilization. J Nutr 25: 17-21, 1943

17. Beadles JR, Mitcheil HH, and Hamilton TS: The utilization of dietary calcium by growing albino rats fed diets containing lard or cocoa butter. J Nutr 45: 399-405, 1951

18. Chatterjee AK: Studies on the involvement of testicular hormone in the regulation of pyridoxal phosphate formation by the kidney tissue. Endocrinology 90: 880884, 1972

19. Hawk PB and Oser BL: A modification of the OSBORNE-MENDEL salt mixture. Science 74: 369, 1931

20. Chatterjee AK, Jamdar SC, and Ghosh BB: Effect of riboflavin deficiency on incorporation in vivo of $\left[{ }^{14} \mathrm{C}\right]$ amino acid into liver proteins of rats. $\mathrm{Br} \mathrm{J}$ Nutr 24: 635640,1970

21. Chatterjee AK and Datta SC: Some studies on the formation in vivo of pyridoxal phosphate in rats receiving high-fat diet. J Vitaminol 18: 189-193, 1972

22. Levine RM, Blair MR, and Clerk BB: Factors influencing the intestinal absorption of certain monoquarternary anticholinergic compounds with special reference to benzomethamine [(N-diethyl aminoethyl- $\mathrm{N}^{\prime}$-methylbenzilamine methobromide (MC-3199)]. J Pharmacol Exp Ther 114: 78-86, 1955

23. Singh R, Nagapaul JP, Majumdar $S$, Chakravarty RM, and Dhail Gl: Effects of $17 \beta$-estradiol and progesterone on intestinal digestive and absorptive functions in ovariectomized rats. Biochem Int 10: 777-786, 1985

24. Adeniyi $\mathrm{KO}$, Ogunkeye $\mathrm{OO}$, and Isichei $\mathrm{CO}$ : Thyroidectomy and thyroxine administration alter serum calcium levels in rat. Acta Physiol Hungarica 81: 95-99, 1983
25. Maenz DD and Cheeseman $\mathrm{Cl}$ : Effect of hyperglycemia on D-glucose transport across the brush border and basolateral membrane of rat intestine. Biochim Biophys Acta 860: 277-285, 1986

26. Koyama I, Komoda T, Sakagishi $Y$, and Kurata M: A possible mechanism for the changes in hepatic and intestinal alkaline phosphatase activities in bile-duct-ligated rats or guineapigs. Biochim Biophys Acta 760: 169-174, 1983

27. Lowry $\mathrm{OH}$, Rosebrough $\mathrm{NJ}$, Farr $\mathrm{AL}$, and Randall RJ: Protein measurement with the Folin-phenol reagent. J Biol Chem 193: 265-275, 1951

28. Rorive $\mathrm{G}$ and Kleinzellar $\mathrm{A}$ : $\mathrm{Ca}^{2+}$-activated ATPase from renal tubular cells. Method Enzymol 32: 303-306, 1974

29. Lowry $\mathrm{HO}$ and Lopez AJ: The determination of inorganic phosphate in the presence of labile phosphate esters. J Biol Chem 162: 421-428, 1946

30. Nath RL: Practical Biochemistry in Clinical Medicine, Academic Publishers, Calcutta, 2nd ed, pp 8-9, 1990

31. Stubbs CD and Smith AD: The modification of mammalian membrane polyunsaturated fatty acid composition in relation to membrane fluidity and function. Biochim Biophys Acta 779: 89-137, 1984

32. Wils MR: Intestinal absorption of calcium. Lancet 2: 820-823, 1973

33. Pike JW, Spanos $E$, Colstan KW, Maclntyre I, and Haussler MR: Influence of estrogen on renal vitamin D hydroxylases and serum $1,25 \mathrm{DHCC}$ in chicks. Am J Physiol 235: E338-E343, 1978

34. Marshall DH and Nardin BEC: The effect of 1-hydroxy vit $D_{3}$ with and without estrogen on calcium balance in postmenopausal women. Clin Endocrinol 7: 15951685, 1979

35. Baksi SN and Kenny AD: Vitamin D metabolism in Japanese quail: Gonadal hormones and dietary calcium effects. Am J Physiol 2: 622-628, 1978

36. Hardley ME: Endocrinology, Prentice Hall international, 2nd ed, p 199, 1988

37. Gallagher JC, Riggs BL, Eisman J, Hamstra A, Arnaud $\mathrm{SB}$, and Deluca HF: Intestinal calcium absorption and serum vitamin D metabolites in normal subjects and osteoporotic patients: Effect of age and dietary calcium. J Clin Invest 64: 729-736, 1979

38. Toofanian $\mathrm{F}$ and Teshfam M: Alkaline phosphatase activity in the small intestine of the sheep. Res Vet Sci 24: 382-383, 1978

39. Wasserman $\mathrm{RH}$ and Fullmer CS: Calcium transport proteins, calcium absorption and vitamin D. Annu Rev Physiol 45: 375-390, 1983

40. Lindsay R, Coutts JRT, and Hart DM: The effect of endogenous oestrogen on plasma and urinary calcium and phosphate in oophorectomized women. Clin Endocrinol 6: 87-93, 1977

41. Aurbach GD, Marx S.J, and Spiegel A.M: Metabolic bone disease. In Williams Text Book of Endocrinology, ed. Wilson JD and Foster DW, W.B. Saunders Co, Philadelphia, 8th ed, p 1505, 1992 